\title{
Differential Responses to Heat Stress in Activities and Isozymes of Four Antioxidant Enzymes for Two Cultivars of Kentucky Bluegrass Contrasting in Heat Tolerance
}

\author{
Yali He \\ State Key of Agrobiotechnology, Department of Plant Sciences, School of Agriculture and Biology, \\ Shanghai Jiao Tong University, Shanghai 201101, People's Republic of China \\ Bingru Huang ${ }^{1}$ \\ Department of Plant Science, Cook College, Rutgers University, New Brunswick, NJ 08901-8520
}

AdDitional INDEX wORDS. superoxide dismutase, catalase, ascorbate peroxidase, guaiacol-peroxidase

\begin{abstract}
Understanding antioxidant mechanisms for heat stress is important for improving heat tolerance in coolseason plant species. The objective of this study was to identify antioxidant enzymes associated with cultivar variations in heat tolerance in kentucky bluegrass (Poa pratensis) by comparing heat responses of activity and isoforms of antioxidant enzymes in two cultivars contrasting in heat tolerance. Plants of heat-tolerant 'Eagleton' and heat-sensitive 'Brilliant' were exposed to $20^{\circ} \mathrm{C}$ (control) or $40{ }^{\circ} \mathrm{C}$ (heat stress) for 28 days in growth chambers. Chlorophyll $(\mathrm{Chl})$ a content remained unchanged and $\mathrm{Chl} b$ content increased in 'Eagleton', while both of them decreased in 'Brilliant', and by 28 days, 'Eagleton' had significantly higher Chl a and b content than 'Brilliant'. The activities of superoxide dismutase (SOD) were significantly higher in 'Eagleton' than in 'Brilliant' by 28 days of heat stress. An isozyme SOD2 was induced early during heat stress in 'Eagleton', while isozyme SOD3 degraded, to a lesser extent in 'Eagleton' than in 'Brilliant'. Catalase (CAT) activity significantly increased in 'Brilliant' but remained constant in 'Eagleton', and 'Brilliant' had a significantly higher CAT activity and isozyme CAT1 than 'Eagleton' during heat stress. Significant increases in ascorbate peroxidase (APX) activities occurred under heat stress, to a greater extent in 'Eagleton', whereas isozymes did not exhibit difference between cultivars. Guaiacol-peroxidase (POD) activity declined during heat stress in both cultivars. The intensity of POD isozymes in 'Brilliant' remained constant, while 'Eagleton' showed a transient increases in POD1 at 7 days of heat stress. Our results indicated that antioxidant defense mechanisms for heat tolerance in kentucky bluegrass could be mainly associated with changes in activity and forms of isozymes of SOD for $\mathrm{O}_{2}$ scavenging and APX activity for $\mathrm{H}_{2} \mathrm{O}_{2}$ scavenging under heat stress.
\end{abstract}

The optimum temperatures for cool-season grass growth are between 15 and $24{ }^{\circ} \mathrm{C}$ (Beard, 1973). High temperatures for prolonged periods during summer in transitional and warm climatic regions often cause turf quality decline, which is characterized by leaf senescence. Leaf chlorophyll (Chl) content is a good indicator of leaf senescence, and both forms of $\mathrm{Chl}$ a and $\mathrm{Chl} \mathrm{b}$ are components of peripheral antenna complexes and complement each other in absorbing sunlight for photosynthesis (Streitweiser and Heathcock, 1976). Alleviating heat-induced leaf senescence is critical in maintaining high visual quality of cool-season species during periods of high temperatures.

Abiotic stresses, including heat stress, cause the production of reactive oxygen species (ROS), resulting in oxidative damage that has been associated with stress-induced leaf senescence (Foyer et al., 1994; Gong et al., 1997; Scandalios, 1992; Zhang and Kirkham, 1996). Oxidative stress can cause lipid peroxidation and, consequently, membrane injury, protein degradation, and enzyme inactivation (Meriga et al., 2004; Sairam et al., 2000). Intracellular membrane damage due to ROS can cause pigment breakdown (Scandalios, 1993). Multiple antioxidant

Received for publication 19 Jan. 2010. Accepted for publication 9 Mar. 2010. The Rutgers Center for Turfgrass Science provided funding support for this work.

We thank Emily Merewitz and Yan Xu for reviewing the manuscript.

${ }^{1}$ Corresponding author. E-mail: huang@aesop.rutgers.edu. enzyme systems are involved in the enzymatic scavenging of ROS. Superoxide dismutase (SOD) is the enzyme for $\mathrm{O}_{2}$ scavenging in the first step of ROS metabolism (Elstner, 1982). Its activity determines the concentrations of $\mathrm{O}_{2}$ and $\mathrm{H}_{2} \mathrm{O}_{2}$, the two Haber-Weiss action substrates, and it is therefore likely to be central in the defense mechanism (Bowler et al., 1992). Hydrogen peroxide is scavenged by catalase (CAT) and peroxidases, which convert hydrogen peroxide to water and molecular oxygen (Bowler et al., 1992). Ascorbate peroxidase (APX) is characterized by its high degree of specificity for ascorbate as the electron donor and by its physiological role in the scavenging of hydrogen peroxide (Asada, 1992; Asada et al., 1993). Guaiacol peroxidases (POD) are characterized by their broad specificity, with guaiacol and pyrogallol as electron donors in assays of their activities (Amako et al., 1994).

Heat stress induces oxidative stress and alters antioxidant enzyme activities in many plant species (Foyer et al., 1994; Gong et al., 1997), including turfgrass species (Jiang and Huang, 2001a, 2001b; Larkindale and Huang, 2004; Liu and Huang, 2000). Decreases, increases, and unchanged activities of antioxidant enzymes were reported, depending on specific enzymes, stress duration, the level of temperatures, and plant species (Almeselmani et al., 2006; Chaitanya et al., 2002; Dat et al., 1998; Foyer et al., 1997; Sairam et al., 2000). Plant species and cultivars with superior heat tolerance generally have been associated with maintaining higher antioxidant enzyme activities 
(Liu and Huang, 2000; Scandalios, 1993). Several studies in cool-season turfgrass species investigated changes in antioxidant enzymes with heat stress (Jiang and Huang, 2001b; Liu and Huang, 2000; Wang et al., 2003). Plants have multiple isozyme forms of antioxidant enzymes, which may be differentially responsive to developmental events and environmental factors (Lee and An, 2005; Mori et al., 1992; Scandalios, 1993). For example, wheat (Triticum aestivum) leaves had three isoforms of Mn-SOD, one isoform of Fe-SOD and $\mathrm{Cu} / \mathrm{Zn}-\mathrm{SOD}$, and the response of enzyme isoforms to drought stress varied between two cultivars differing in drought tolerance (Zhang et al., 2004). Multiple isoforms of CAT are found in many plant species and are differentially regulated by developmental events and environmental factors (Mori et al., 1992). Four CAT isoforms were identified in Bruguiera parviflora in response to salt stress, among which the prominent CAT-2 isoform level was reduced more than other isoforms, suggesting differential down-regulation of CAT isoforms by $\mathrm{NaCl}$ (Parida et al., 2004). This study concluded that the differential changes in the level of isoforms may be useful markers for identifying salt tolerance. Despite previous research on antioxidant enzymes in relation to heat tolerance, specific antioxidant enzymes, particularly the isozyme forms associated with heat tolerance in cool-season turfgrasses, have not yet been documented.

Kentucky bluegrass is a cool-season turfgrass widely used in temperate zones. Turf quality decline associated with leaf senescence is a major concern in kentucky bluegrass lawn and golf turf management. There exists a wide range of genetic variability in summer stress tolerance in this grass species (Bonos and Murphy, 1999). Understanding genetic variations in responses to antioxidant enzyme activities and isozyme forms to heat stress may shed light on antioxidant mechanisms for heat tolerance in cool-season grass species. The objective of this study was to identify antioxidant enzymes associated with heat tolerance in kentucky bluegrass by comparing responses of enzyme activity and isozymes to heat stress in two cultivars contrasting in heat tolerance.

\section{Materials and Methods}

Plant materials and growth Conditions. The heat-tolerant kentucky bluegrass cultivar Eagleton and the heat-sensitive cultivar Brilliant (He and Huang, 2007) were examined. Sod plugs of 'Brilliant' and 'Eagleton' were collected from 3-yearold field plots at Horticulture Farm II, Rutgers University, North Brunswick, NJ, and were transferred into PVC pots $(20 \mathrm{~cm}$ in diameter and $25 \mathrm{~cm}$ in height with holes at the bottom for drainage) filled with a mixture $(1: 3, \mathrm{v} / \mathrm{v})$ of sand and soil (fineloamy, mixed mesic Typic Hapludult). Plants were maintained in a greenhouse for $60 \mathrm{~d}$ and were then moved into growth chambers. The greenhouse had an average day/night temperature of $21 / 14{ }^{\circ} \mathrm{C}$, photosynthetically active radiation $(P A R)$ of 680 $\mu \mathrm{mol} \cdot \mathrm{m}^{-2} \cdot \mathrm{s}^{-1}$, and a $12-\mathrm{h}$ photoperiod. The chambers were set at $20 / 15^{\circ} \mathrm{C}$ (day/night temperature), $75 \%$ of relative humidity, a 14-h photoperiod, and $500 \mu \mathrm{mol} \cdot \mathrm{m}^{-2} \cdot \mathrm{s}^{-1} P A R$. Plants were fertilized once per week with $40 \mathrm{~mL}$ of full-strength Hoagland's solution (Hoagland and Arnon, 1950) and were cut twice a week to keep the height at $\approx 10 \mathrm{~cm}$. For all treatments, pots were watered three times per week until drainage occurred at the bottom of the pot at each irrigation.

Heat Stress treatments. Plants were allowed to acclimate to growth chamber conditions for $14 \mathrm{~d}$ before temperature treatments were imposed. All plants were cut to the canopy height of $10 \mathrm{~cm} 2 \mathrm{~d}$ before heat stress treatments were imposed to start with a uniform turf canopy. Eight pots of plants (four pots for each cultivar as four replicates) were maintained at 20/ $15^{\circ} \mathrm{C}$ (day/night) as the optimum growth temperature control, while another set of eight pots of plants (four pots for each cultivar as four replicates) were exposed to $40 / 35{ }^{\circ} \mathrm{C}$ (day/ night), which imposed heat stress. Plants were watered twice per day to maintain soil water content at the field capacity $(27 \%)$. Other environmental conditions and fertility were the same as during the growing period described above.

Plants were treated to heat stress for $28 \mathrm{~d}$. Leaf samples were collected every $7 \mathrm{~d}$, which was on $0 \mathrm{~d}$ (control at $20 / 15^{\circ} \mathrm{C}$ ), and $7,14,21$, and $28 \mathrm{~d}$ of the heat stress treatment. Fresh leaf tissues were collected from different areas of the turf canopy in each pot at each sampling date to measure content of Chl a, Chl b, salt-soluble protein, and tissue dry weight. Leaf samples for enzyme analysis were frozen in liquid nitrogen and kept at $-70{ }^{\circ} \mathrm{C}$ until use.

LeAF SENESCENCE MeASUREMENTS. The content of Chl a and Chl b was measured to evaluate the level of leaf senescence during heat stress. Chlorophyll was extracted by soaking $0.1 \mathrm{~g}$ of leaves in $10 \mathrm{~mL}$ of dimethyl sulfoxide for $72 \mathrm{~h}$ (Hiscox and Israelstam, 1979). Absorbance of chlorophyll extracts was measured at 663 and $645 \mathrm{~nm}$ with a spectrophotometer (Genesys 2; Spectronic Instruments, Rochester, NY). Content of Chl $\mathrm{a}$ and Chl b was calculated using the formula of Arnon (1949).

Enzyme EXTRACTION. Frozen leaves $(0.5 \mathrm{~g})$ were ground in liquid $\mathrm{N}_{2}$ and extracted in $2 \mathrm{~mL}$ of $150 \mathrm{mmol}$ PBS (pH 7.0) kept in ice for SOD, CAT, and POD extraction, and in PBS ( $\mathrm{pH}$ 7.0) containing $5 \mathrm{mmol}$ ascorbate and $1 \mathrm{mmol}$ EDTA (Mittler and Zilinskas, 1993) for APX in an ice-water bath. The homogenate was centrifuged twice at $16,000 g_{n}$ at $4{ }^{\circ} \mathrm{C}$ for $30 \mathrm{~min}$. Supernatant was stored at $4{ }^{\circ} \mathrm{C}$ before measurement and in an icewater bath during measurement.

ENZYME ACTIVITY ASSAYS. Superoxide dismutase activity was determined by measuring its ability to inhibit the photochemical reduction of nitroblue tetrazolium chloride (NBT), according to the method of Giannopolitis and Ries (1977) with slight modifications. The reaction solution $(3 \mathrm{~mL})$ contained $37 \mathrm{mmol}$ PBS $(\mathrm{pH} 7.8), 4 \times 10^{-3} \mathrm{mmol}$ riboflavin (7,8-dimethyl-10ribitylisoalloxazine), $13 \mathrm{mmol}$ methionine [2-amino-4-(methylthio)-butyric acid], $1 \times 10^{-4} \mathrm{mmol}$ EDTA, $0.08 \mathrm{mmol} \mathrm{NBT}$, and $50 \mu \mathrm{L}$ of enzyme extract. Reaction solution was irradiated under incandescent lights at $1000 \mu \mathrm{mol} \cdot \mathrm{m}^{-2} \cdot \mathrm{s}^{-1}$ for $40 \mathrm{~min}$. Absorbance of reaction solution at $560 \mathrm{~nm}$ was determined with the spectrophotometer as described above. One unit of enzyme activity was defined as the amount of the enzyme bringing $50 \%$ inhibition of the photochemical reduction of NBT.

Catalase activity was assayed by measuring the rate of decomposition of $\mathrm{H}_{2} \mathrm{O}_{2}$ at $240 \mathrm{~nm}$ in $3 \mathrm{~mL}$ of reaction mixture consisting of $50 \mathrm{mmol} \mathrm{PBS}$ [pH 7.4 (He et al., 2001)] and 15 mmol $\mathrm{H}_{2} \mathrm{O}_{2}$ (modified method of Aebi, 1984). Absorbance of reaction solution at $240 \mathrm{~nm}$ was determined every $10 \mathrm{~s}$ six times with a spectrophotometer (Genesys 2). One unit of enzyme was defined as the decrease in absorbance by 1 at $240 \mathrm{~nm}$ as $\mathrm{H}_{2} \mathrm{O}_{2}$ was decomposed.

Ascorbate peroxidase activity was measured by monitoring the decrease in absorbance at $290 \mathrm{~nm}$ as ascorbate was oxidized in reaction solution, as described by Nakano and Asada (1981) with slight modification. Twenty-five microliters of enzyme extract was added to $3 \mathrm{~mL}$ of reaction solution containing 
0.1 mmol HAC-NaAC buffer [pH 5.8 (He et al., 2001)], $1 \times 10^{-4}$ mmol EDTA, $8.3 \times 10^{-2} \mathrm{mmol} \mathrm{H}_{2} \mathrm{O}_{2}$, and $0.17 \mathrm{mmol}$ ascorbate. Absorbance of reaction solution at $290 \mathrm{~nm}$ was determined every $10 \mathrm{~s}$ six times with the spectrophotometer as described above. One unit of enzyme was defined as the decrease in absorbance by 1 at $290 \mathrm{~nm}$ as ascorbate was oxidized.

Guaiacol peroxidase activity was determined by monitoring the increase in absorbance at $470 \mathrm{~nm}$ as guaiacol was oxidized, according to the method of Chance and Maehly (1955) with slight modification. The assay mixture contained $0.07 \%$ HACNaAC buffer [pH 5.0 (He et al., 2001)], 0.08\% guaiacol, 0.03\% $\mathrm{H}_{2} \mathrm{O}_{2}$, and $25 \mu \mathrm{L}$ of enzyme extract. The total reaction mixture was $3.0 \mathrm{~mL}$. Absorbance of reaction solution at $470 \mathrm{~nm}$ was determined every $10 \mathrm{~s}$ six times with the spectrophotometer, as described above. One unit of enzyme was defined as the increase in absorbance by 1 at $470 \mathrm{~nm}$ as guaiacol was oxidized.

ELECTROPHORESIS FOR ISOZYME ASSAYS. Samples were subjected to discontinuous polyacrylamide gel electrophoresis under nondenaturing, nonreducing conditions as described by Laemmli (1970) with some modifications. SOD was detected on $10.8 \%$ acrylamide gels, and GPX, CAT, and APX were detected on $7.2 \%$ gels. Protein in $66 \mu \mathrm{g}$ for SOD and CAT and 68 $\mu \mathrm{g}$ for APX and GPX were loaded on each gel. Electrophoresis was carried out using a Mini-Protean system (Bio-Rad Laboratories, Hercules, CA) at $20{ }^{\circ} \mathrm{C}$ for 5 to $6 \mathrm{~h}$ in $0.04 \mathrm{~mol}$ Tris (hydroxymethyl) aminomethane-glycine buffer $(\mathrm{pH} 8.3$ ) for SOD, GPX, CAT, and in the same buffer with addition of 2 mmol ascorbate for APX.

ISOZYMES VISUALIZATION. The SOD isozymes were detected using the NBT staining method according to Beauchamp and Fridovich (1973) with modification. Briefly, the gels were soaked in $100 \mathrm{~mL}$ of staining solution containing $2.45 \times 10^{-3}$ M NBT for $20 \mathrm{~min}$ in the dark, and were then soaked in $100 \mathrm{~mL}$ of solution containing $5.6 \times 10^{-5} \mathrm{M} \mathrm{VB}_{2}, 2.8 \times 10^{-2} \mathrm{~N}, \mathrm{~N}, \mathrm{~N}^{\prime}$, N'tetramethylethylenediamine (TEMED), and $3.6 \times 10^{-2} \mathrm{PBS}(\mathrm{pH}$ 7.8) for $15 \mathrm{~min}$ in the dark, and finally soaked in a solution containing $1 \times 10^{-4}$ EDTA and $5 \times 10^{-2} \mathrm{M}$ PBS $(\mathrm{pH} 7.8)$. The gels were exposed to incandescent lights at $1000 \mu \mathrm{mol} \cdot \mathrm{m}^{-2} \cdot \mathrm{s}^{-1}$ for $40 \mathrm{~min}$ or until the transparent bands (SOD isozymes) were visible.

The CAT isozyme staining was performed according to Woodbury et al. (1971) with modifications. After gel electrophoresis, the gel was washed in three changes of distilled water for a total of about 6 min to remove the buffer from the gel surface where staining occurred. The gel was then soaked in $0.3 \% \mathrm{H}_{2} \mathrm{O}_{2}$ for $15 \mathrm{~min}$ at $20^{\circ} \mathrm{C}$ in the dark with light agitation, and then in the stain mixture containing $1 \%(\mathrm{w} / \mathrm{v}) \mathrm{FeCl}_{3}$ and $1 \%$ $(\mathrm{w} / \mathrm{v}) \mathrm{K}_{3} \mathrm{Fe}(\mathrm{CN})_{6}$ in distilled water under $20{ }^{\circ} \mathrm{C}$ for $10 \mathrm{~min}$ or until the light yellow bands (CAT isoenzymes) were visible.

All the steps of detection of APX isozymes in the gels were performed according to the procedure described in Mittler and Zilinskas (1993). After the electrophoretic separation, the gels were equilibrated with $0.1 \mathrm{mmol}$ sodium acetate buffer ( $\mathrm{pH}$ 5.8) and $2 \mathrm{mmol}$ ascorbate for $30 \mathrm{~min}$; the equilibration buffer was changed three times every $10 \mathrm{~min}$. The gels were then incubated for $20 \mathrm{~min}$ in $0.1 \mathrm{mmol}$ sodium acetate buffer containing $4 \mathrm{mmol}$ ascorbate and $2 \mathrm{mmol} \mathrm{H}_{2} \mathrm{O}_{2} \cdot \mathrm{H}_{2} \mathrm{O}_{2}$ was added to this solution immediately before the incubation of the gel. The gels were subsequently washed with $0.1 \mathrm{mmol}$ sodium acetate buffer for $1 \mathrm{~min}$ and submerged in a solution of $0.1 \mathrm{mmol}$ sodium acetate buffer, $28 \mathrm{mmol}$ TEMED, and $2.45 \mathrm{mmol} \mathrm{NBT}$ with gentle agitation. The gels were exposed to incandescent lights at $1000 \mu \mathrm{mol} \cdot \mathrm{m}^{-2} \cdot \mathrm{s}^{-1}$ for $10 \mathrm{~min}$. The APX activity isozymes were observed as an achromatic band.

Guaiacol peroxidase isozymes were detected using the benzidine acetate staining method modified from Ros Barceló et al. (1987). The gel was incubated in a staining solution containing $0.074 \%$ ascorbate, $20 \%$ benzidine solution $[2.2 \%$ benzidine in $18 \%(\mathrm{v} / \mathrm{v})$ acetic acid], and $0.12 \% \mathrm{H}_{2} \mathrm{O}_{2}$ for $3 \mathrm{~min}$. The gels were subsequently destained in $7 \%(\mathrm{v} / \mathrm{v})$ acetic acid for several seconds until the bands were visible in dark brown.

In all gels, bromophenol blue was used as the marker for estimating the relative mobility ( $\mathrm{Rf}$ ) values of isozymes (Bernardi et al., 2001), which indicates the mobility of enzyme bands relative to the mobility of the bromophenol blue front. The isozymes were defined or numbered by their $\mathrm{Rf}$ in order from the cathode to the anode.

EXPERIMENTAL DESIGN AND STATISTICAL ANALYSIS. Treatments were arranged in a randomized complete block design with four replicates (four pots of each treatment). For enzyme activity measurement, each extraction sample (replicate) was measured three times (three subsamples per replicate). The mean of the three subsamples was used to represent a single replicate in the analysis of variance. Effects of control and high temperature and cultivar variations under the temperature treatments were analyzed with analysis of variance using Excel 2000 (Microsoft, Redmond, WA) (Levine et al., 2001), and mean separations were performed with the Fisher's protected least significance difference test at $P=0.05$ (Steel and Torrie, 1980). Cultivars did not differ in any of the parameters measured under control temperature conditions and exhibited no significant changes over temperature treatment duration. Therefore, only the data concerning cultivar variations under heat stress and changes in each parameter with heat stress duration are presented and discussed.

\section{Results}

Chlorophyll a AND Chlorophyll B CONTENT. At the initiation of heat stress or before heat stress $(0 \mathrm{~d})$, 'Brilliant' had a significantly higher Chl a content than 'Eagleton' (Fig. 1A). The content of Chl a was constant during heat stress in 'Eagleton'; it was significantly higher in 'Brilliant' than in 'Midnight' from 0 to $14 \mathrm{~d}$ of heat stress, but decreased significantly after $14 \mathrm{~d}$ of heat stress in 'Brilliant'. By $28 \mathrm{~d}$ of heat stress, Chl a content was significantly higher in 'Eagleton' than in 'Brilliant'.

$\mathrm{Chl} \mathrm{b}$ content increased significantly at $14 \mathrm{~d}$ and the elevated level was sustained at $28 \mathrm{~d}$ of heat stress in 'Eagleton', but decreased significantly by $28 \mathrm{~d}$ of heat stress in 'Brilliant' (Fig. 1B). By the $28 \mathrm{~d}$ of heat stress, 'Eagleton' had significantly higher Chl b content than 'Brilliant'.

SuPEROXIDE DiSMUTASE ACTIVITY AND ISOZYME PROFILES. Before heat stress $(0 \mathrm{~d})$, SOD activities did not differ between 'Eagleton' and 'Brilliant' (Fig. 2). During heat stress, SOD activity remained unchanged in 'Eagleton', but decreased significantly at 21 and $28 \mathrm{~d}$ of heat stress. At $28 \mathrm{~d}$ of heat stress, SOD activity was significantly higher in 'Eagleton' than in 'Brilliant'.

Both cultivars had five SOD isozymes with Rf of $0.19,0.50$, $0.82,0.85$, and 0.89 before heat stress $(0 \mathrm{~d})$ (Fig. 3$)$. SOD2 with Rf 0.36 was induced in 'Eagleton' at $7 \mathrm{~d}$ of heat stress and in 'Brilliant' at 14 and $21 \mathrm{~d}$. The intensity of SOD3 with Rf 0.5 decreased in 'Brilliant' at $28 \mathrm{~d}$ of heat stress, but was maintained in 'Eagleton'. Other isozymes did not change during heat stress in either cultivar. 

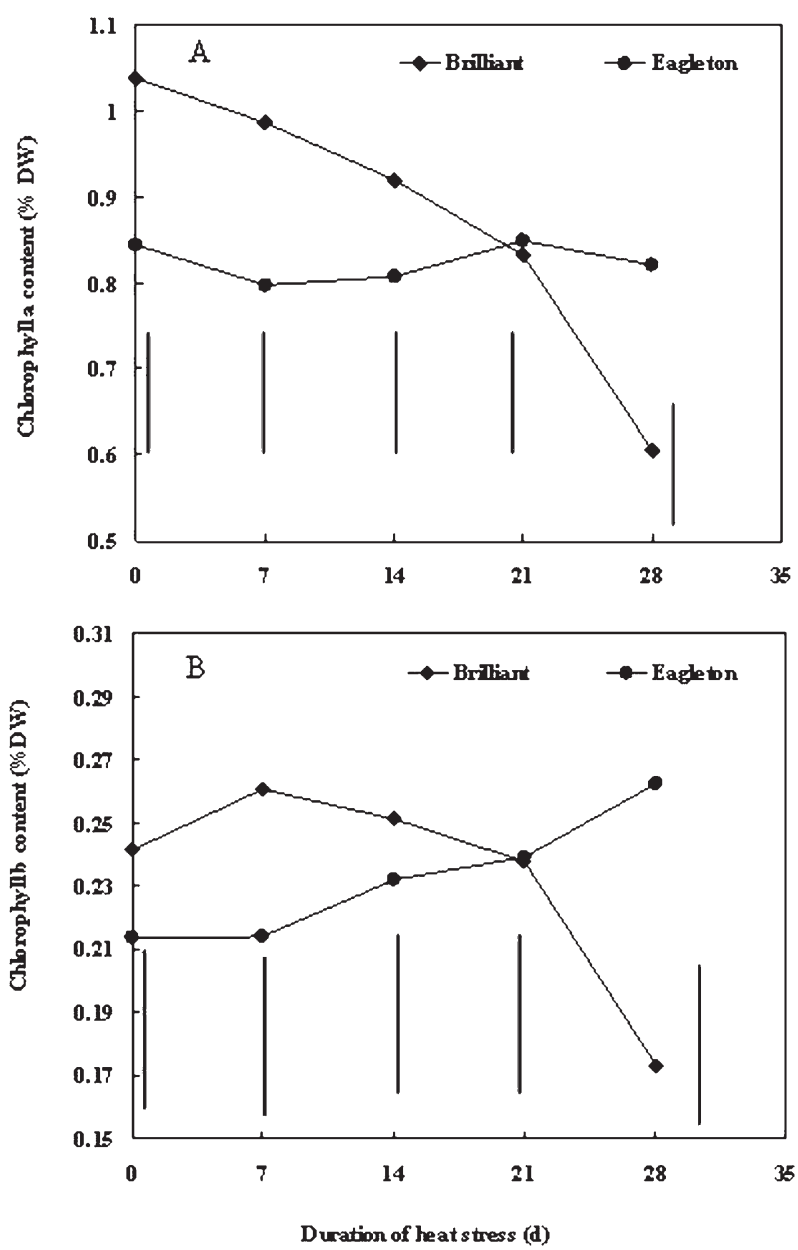

Fig. 1. Changes in chlorophyll a content (A) and chlorophyll b content (B) of 'Brilliant' and 'Eagleton' kentucky bluegrass during heat stress. Vertical bars at the bottom represent LSD values at $P=0.05$ for comparisons between cultivars at a given day of treatment. The LSD values $(P=0.05)$ for comparisons of chlorophyll a and chlorophyll $\mathrm{b}$ over time in both cultivars were 0.082 and 0.025 , respectively.

Changes in Catalase aCtivity and isozyme pRofiles. In 'Brilliant', CAT activity increased significantly at $7 \mathrm{~d}$, the elevated activity was sustained at $21 \mathrm{~d}$, and it then decreased to its control level by $28 \mathrm{~d}$ of heat stress. The activity of CAT did not change significantly from 0 to $28 \mathrm{~d}$ of heat stress (Fig. 4). The activity of CAT did not differ between the two cultivars before heat stress, but was significantly higher in 'Brilliant' than in 'Eagleton' under heat stress.

No CAT isozymes were present at $0 \mathrm{~d}$ of heat stress for either cultivar (Fig. 5). Two isozymes ( $\mathrm{Rf}$ of 0.15 and 0.21 ) were detected under heat stress in 'Brilliant' at 7, 14, and $21 \mathrm{~d}$ of heat stress. Only one isozyme, CAT2 (Rf of 0.21 ), was detected in 'Eagleton' during heat stress.

Changes IN ASCORBATE PEROXIDASE ACTIVITY AND ISOZYME PROFILES. No significant differences in APX activities were observed between the two cultivars before heat stress $(0 \mathrm{~d})$ (Fig. 6). The activity of APX increased significantly in 'Eagleton' during $28 \mathrm{~d}$ of heat stress. It increased up to $14 \mathrm{~d}$ and then decreased afterward in 'Brilliant'. The activity of APX was significantly higher in 'Eagleton' than in 'Brilliant' at $28 \mathrm{~d}$ of heat stress, but not at 7 to $21 \mathrm{~d}$.

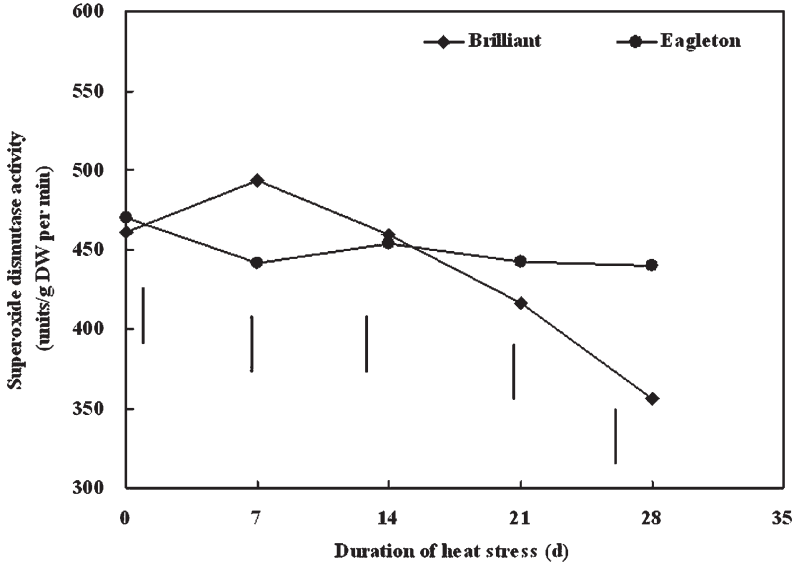

Fig. 2. Changes in superoxide dismutase (SOD) activities of 'Brilliant' and 'Eagleton' kentucky bluegrass during heat stress. Vertical bars at the bottom represents LSD values at $P=0.05$ for comparisons between cultivars at a given day of treatment. The LSD value $(P=0.05)$ for comparisons over time of SOD activity in both cultivars was 19.45 .

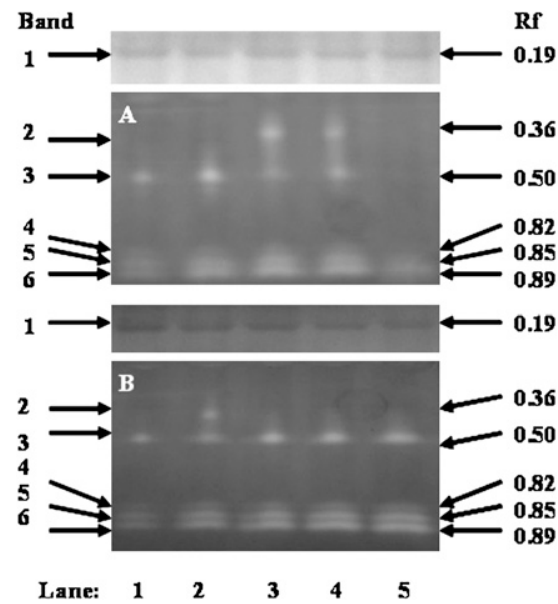

Fig. 3. Changes in superoxide dismutase (SOD) isoforms of 'Brilliant' $(\mathbf{A})$ and 'Eagleton' (B) kentucky bluegrass during heat stress. Equal amounts $(90 \mu \mathrm{g})$ of protein were loaded in each lane: lane $1=20^{\circ} \mathrm{C}(0 \mathrm{~d}$ of heat stress $)$, lane $2=$ $40{ }^{\circ} \mathrm{C}$ for $7 \mathrm{~d}$, lane $3=40^{\circ} \mathrm{C}$ for $14 \mathrm{~d}$, lane $4=40^{\circ} \mathrm{C}$ for $21 \mathrm{~d}$, lane $5=40^{\circ} \mathrm{C}$ for $28 \mathrm{~d} ; \mathrm{Rf}=$ relative mobility (i.e., relative electrophoretic mobility with respect to the bromophenol blue band).

Both cultivars had three APX isozymes (Fig. 7). The changes in APX isozymes during heat stress were similar in both cultivars, with increasing intensity of APX2 ( Rf of 0.58) and APX3 (Rf of 0.75), but APX1 remained unchanged ( $R f$ of $0.16)$.

Changes in guaiacol peroxidase aCtivity AND ISOZYMe PROFILES. Guaiacol peroxidase activity declined during heat stress in both cultivars (Fig. 8). POD activity did not differ significantly between 'Brilliant' and 'Eagleton' before and during heat stress.

Eight POD isozymes were detected before and during heat stress in both cultivars (Fig. 9). The intensity of POD isoenzymes in 'Brilliant' remained unchanged, while the intensity of three isozymes, POD1 (Rf 0.06), POD2 (Rf 0.13), and POD3 (Rf 0.21 ) increased at $7 \mathrm{~d}$ of heat stress and was stronger in 'Eagleton' than in 'Brilliant', but then decreased at 14, 21, and $28 \mathrm{~d}$ of heat stress. 


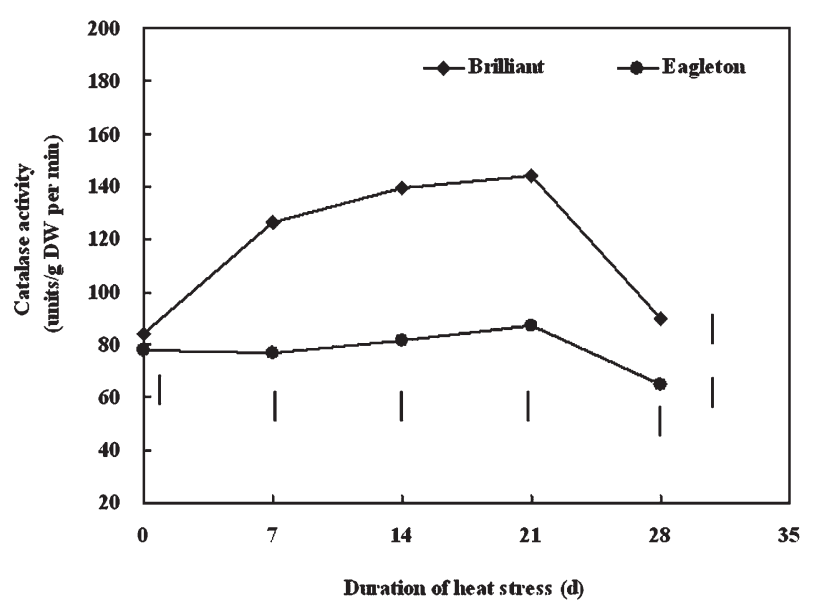

Fig. 4. Changes in catalase (CAT) activities of 'Brilliant' and 'Eagleton' kentucky bluegrass during heat stress. Vertical bars at the bottom represents LSD values at $P=0.05$ for comparisons between cultivars at a given day of treatment. The LSD value $(P=0.05)$ for comparisons over time of CAT activity in both cultivars was 6.11 .
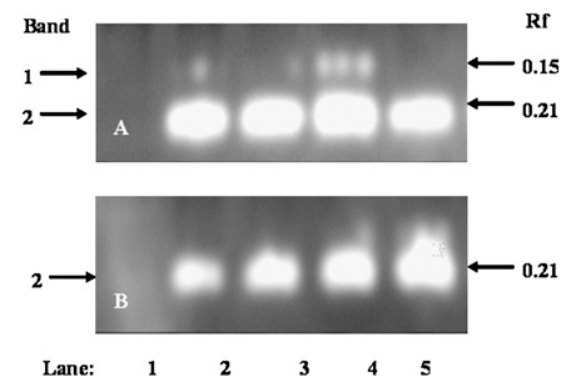

Fig. 5. Changes in catalase (CAT) isoforms of 'Brilliant' (A) and 'Eagleton' (B) kentucky bluegrass during heat stress. Equal amounts $(90 \mu \mathrm{g})$ of protein were loaded in each lane: lane $1=20^{\circ} \mathrm{C}(0 \mathrm{~d}$ of heat stress $)$, lane $2=40{ }^{\circ} \mathrm{C}$ for $7 \mathrm{~d}$, lane $3=40{ }^{\circ} \mathrm{C}$ for $14 \mathrm{~d}$, lane $4=40^{\circ} \mathrm{C}$ for $21 \mathrm{~d}$, lane $5=40^{\circ} \mathrm{C}$ for $28 \mathrm{~d}$; $\mathrm{Rf}=$ relative mobility (i.e., relative electrophoretic mobility with respect to the bromophenol blue band).

\section{Discussion}

Leaf Chl content is an important factor determining photosynthetic capacity. Various studies have shown that heat stress leads to reductions in the content of $\mathrm{Chl}$ a and $\mathrm{Chl} \mathrm{b}$ in coolseason turfgrasses, contributing to leaf senescence and photosynthesis inhibition under heat stress (He and Huang, 2007; Jiang and Huang, 2001a; Liu and Huang, 2000; Zhang et al., 2010). In this study, Chl a and Chl b content decreased significantly in 'Brilliant', but remained constant or even increased (Chl b) in 'Eagleton' under heat stress; in addition, Chl a and Chl b content were significantly higher in 'Eagleton' than in 'Brilliant' following prolonged periods of heat stress (28 d); to a greater degree for Chl b. It was previously reported that Chl b-less mutants of rice (Oryza sativa) were more susceptible to heat stress than wild type, indicating the importance of maintaining Chl b synthesis for heat tolerance (Lin et al., 2005). Our results suggested that 'Eagleton' was better able to maintain leaf chlorophyll synthesis and sustain less degradation, thus it had better heat tolerance compared with 'Brilliant'. These results are consistent with a previous study reporting that 'Eagleton' had superior heat tolerance than 'Brilliant' (He and

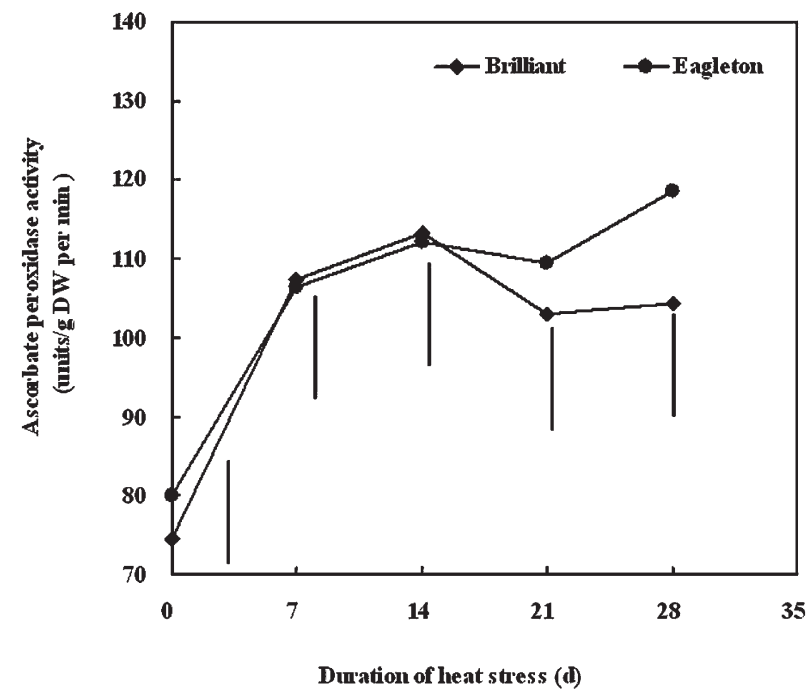

Fig. 6. Changes in ascorbate peroxidase (APX) activities of 'Brilliant' and 'Eagleton' kentucky bluegrass during heat stress. Vertical bars at the bottom represents LSD values at $P=0.05$ for comparisons between cultivars at a given day of treatment. The LSD value $(P=0.05)$ for comparisons over time of APX activity in both cultivars was 8.0 .

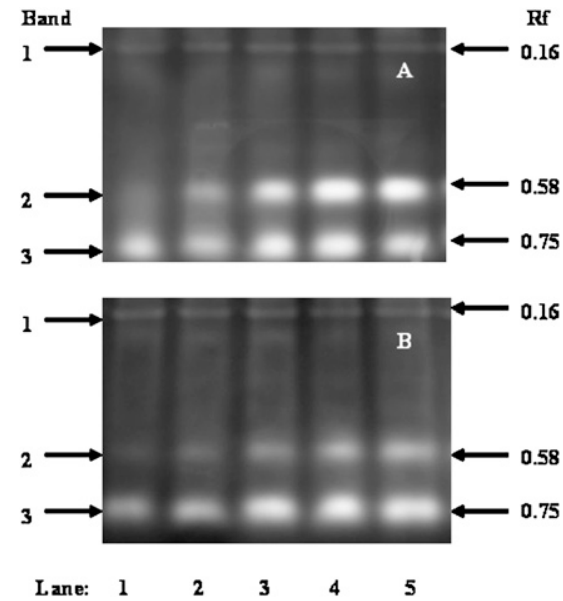

Fig. 7. Changes in ascorbate peroxidase (APX) isoforms of 'Brilliant' (A) and 'Eagleton' (B) kentucky bluegrass during heat stress. Equal amounts (90 $\mu \mathrm{g})$ of protein were loaded in each lane: lane $1=20^{\circ} \mathrm{C}(0 \mathrm{~d}$ of heat stress $)$, lane $2=$ $40^{\circ} \mathrm{C}$ for $7 \mathrm{~d}$, lane $3=40^{\circ} \mathrm{C}$ for $14 \mathrm{~d}$, lane $4=40^{\circ} \mathrm{C}$ for $21 \mathrm{~d}$, lane $5=40^{\circ} \mathrm{C}$ for $28 \mathrm{~d} ; \mathrm{Rf}=$ relative mobility (i.e., relative electrophoretic mobility with respect to the bromophenol blue band).

Huang, 2007). The cultivar variations in heat-induced leaf senescence, as shown in this study and in overall heat tolerance in kentucky bluegrass, as demonstrated by differential physiological responses of the two cultivars reported previously (He and Huang, 2007), could be associated with differential changes in antioxidant defense systems in response to heat stress.

The two cultivars of kentucky bluegrass exhibited different responses of SOD activities and isoenzymes to heat stress. In heat-tolerant 'Eagleton', constant SOD activity was observed during the $28 \mathrm{~d}$ of heat stress, whereas that SOD activity decreased in heat-sensitive 'Brilliant'. Unchanged SOD activity was also detected between heated $\left(42{ }^{\circ} \mathrm{C}\right.$ for $24 \mathrm{~h}$ ) and unheated rice seedlings (Sato et al., 2001). The unaltered SOD 


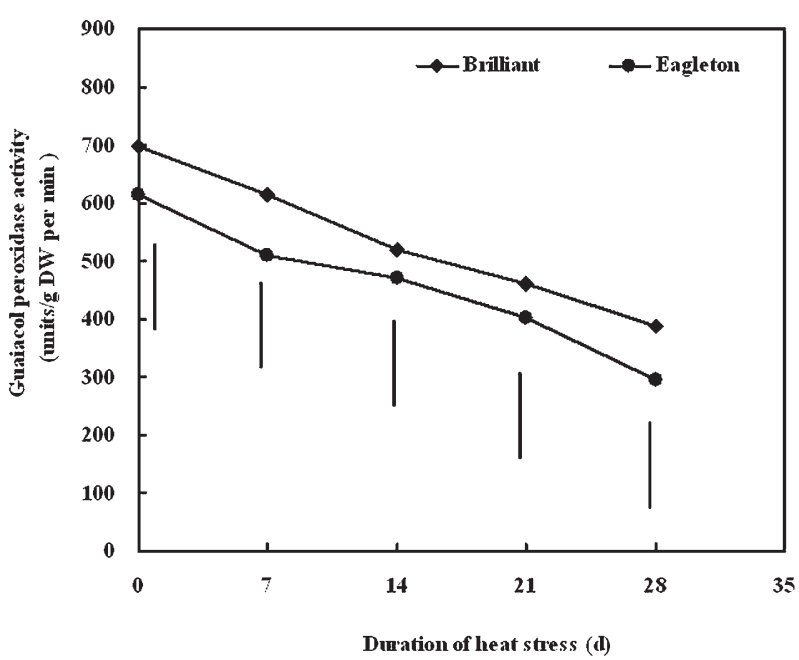

Fig. 8. Changes in guaiacol peroxidase (POD) activities 'Brilliant' and 'Eagleton' kentucky bluegrass during heat stress. Vertical bars at the bottom represents LSD values at $P=0.05$ for comparisons between cultivars at a given day of treatment. The LSD value $(P=0.05)$ for comparisons over time of POD activity in both cultivars was 91.4 .

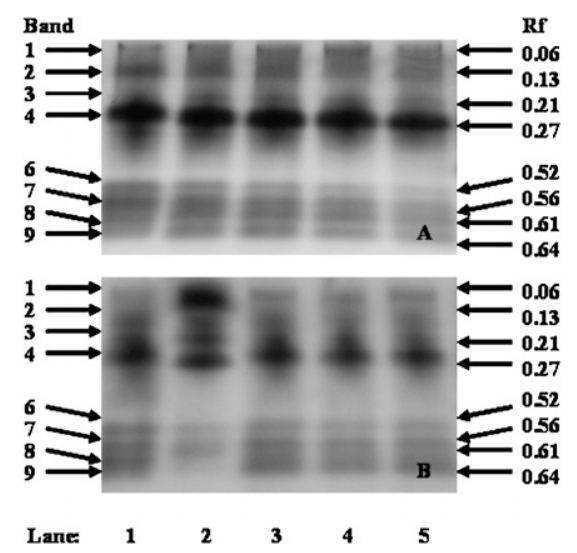

Fig. 9. Changes in guaiacol peroxidase (POD) isoforms of 'Brilliant' (A) and 'Eagleton' (B) kentucky bluegrass during heat stress. Equal amounts ( $90 \mu \mathrm{g})$ of protein were loaded in each lane: lane $1=20^{\circ} \mathrm{C}(0 \mathrm{~d}$ of heat stress $)$, lane $2=$ $40{ }^{\circ} \mathrm{C}$ for $7 \mathrm{~d}$, lane $3=40^{\circ} \mathrm{C}$ for $14 \mathrm{~d}$, lane $4=40^{\circ} \mathrm{C}$ for $21 \mathrm{~d}$, lane $5=40{ }^{\circ} \mathrm{C}$ for $28 \mathrm{~d} ; \mathrm{Rf}=$ relative mobility (i.e., relative electrophoretic mobility with respect to the bromophenol blue band).

activity might reflect that $\mathrm{O}_{2}{ }^{--}$production in the heat-tolerant cultivar was not enhanced as much as in the heat-susceptible cultivar or that heat-tolerant plants were better able to maintain active SOD under heat stress for detoxifying $\mathrm{O}_{2}{ }^{--}$. Increased SOD activity was observed in the leaves of grape (Vitis vinifera) cultivars resistant to lime-induced chlorosis compared with less resistant cultivars (Ostrovskaya et al., 2009). The increased SOD activity was considered a protective mechanism against the formation of superoxide (Ostrovskaya et al., 2009). The maximal steady-state levels of the appropriate SODs might be required at all times to provide adequate protection, as the $\mathrm{O}_{2} \cdot-$ and the products of its peroxidation are highly and immediately toxic to the cell (Scandalios, 1993). The decreased SOD activities in 'Brilliant' may result in less protection of the leaves from attack by the increase of $\mathrm{O}_{2}{ }^{--}$production and thus more severe heat damages in leaves.
Environmental stresses may result in high protein turnover, resulting in the requirement for new SOD enzyme synthesis to maintain SOD levels sufficient for effective protection (Scandalios, 1993). A previous study in Catharanthus roseus (Elkahoui et al., 2005) found that the increase in SOD activity observed in salt-treated cells was associated with increasing amounts of three of five isozymes. In the current study, kentucky bluegrass cultivars exhibited five SOD isozymes. Heat-induced SOD2 (Rf 0.36) was detected in both cultivars, but occurred earlier ( $7 \mathrm{~d})$ in 'Eagleton' than in 'Brilliant' (14 and $21 \mathrm{~d}$ ), which could be involved in scavenging ROS produced during early phase of heat stress. The SOD2 isozymes with Rf 0.36 have been found in the cytoplasm in pea (Pisum sativum cv. Alaska) leaves (Foster and Edwards, 1980). The SOD3 (Rf 0.50), similar to the reported SOD isozyme with Rf 0.52 located in chloroplast in wheat (Triticum aestivum cv. Argee) leaves (Foster and Edwards, 1980), decreased only in 'Brilliant'. The SOD of Rf 0.52 in wheat chloroplast was the predominant SOD, contributing about $80 \%$ of the total SOD isozymes (Foster and Edwards, 1980). Localization of this enzyme in chloroplasts is consistent with a requirement for a more $\mathrm{H}_{2} \mathrm{O}_{2}$-resistant enzyme at a site where generation of $\mathrm{H}_{2} \mathrm{O}_{2}$ occurs (Foster and Edwards, 1980). The reduction of SOD3 (Rf $0.50)$ in 'Brilliant', corresponding to the reduction of SOD activity at $28 \mathrm{~d}$ of heat stress, may account for its high sensitivity to heat stress, while the maintenance of this isozyme in 'Eagleton' could be related to the maintenance of higher SOD activity even after $28 \mathrm{~d}$ of heat stress.

Catalase is the major $\mathrm{H}_{2} \mathrm{O}_{2}$-scavenging enzyme in all aerobic organisms. Reports on the effects of stress on CAT activities vary based on experiment and plant species or cultivars. Decreases in CAT activity has been reported in plants exposed to short-term heat shock in various species (Dat et al., 1998; Foyer et al., 1997; Sato et al., 2001) and during long-term heat stress in perennial grass species (Jiang and Huang, 2001b). In contrast, some studies have reported increases in CAT activity in response to short-term heat stress followed by decreases after prolonged periods of heat treatment (He et al., 2005). Increasing CAT activity may be beneficial to detoxifying $\mathrm{H}_{2} \mathrm{O}_{2}$ induced by heat stress, and also may be a response to the increase in $\mathrm{H}_{2} \mathrm{O}_{2}$ production under stress (Dat et al., 1998; Foyer et al., 1997). In the present study, CAT activity increased during $21 \mathrm{~d}$ of heat stress and then decreased at $28 \mathrm{~d}$ in 'Brilliant', while it was relatively unchanged in 'Eagleton' during $28 \mathrm{~d}$ of heat stress. Our results suggest that higher CAT activity under heat stress in kentucky bluegrass may reflect increases in $\mathrm{H}_{2} \mathrm{O}_{2}$ production associated with heat injury. An increase in CAT activity with heat stress was also observed in other plant species such as wheat (Almeselmani et al., 2006; Sairam et al., 2000).

Multiple isozymes of CAT were found in various plant species that were responsive to environmental factors (Lee and An, 2005). Water stress activates CAT isozymes in droughtinduced oxidative stress events in wheat (Zhang et al., 2004). A transient increase in CAT isozymes was also observed in $\mathrm{NaCl}$ treated barley (Hordeum vulgare) root and shoot (Kim et al., 2005) and $C$. roseus (Elkahoui et al., 2005). In the present study, heat stress induced CAT2 with Rf 0.21 in both cultivars and CAT 1 with $\operatorname{Rf} 0.15$ at 7, 14, and $21 \mathrm{~d}$ of heat stress only in 'Brilliant'. More and stronger CAT isozymes detected in 'Brilliant' during heat stress coincided with the higher CAT activity in 'Brilliant' compared with 'Eagleton'. The higher 
CAT activities and stronger intensity of CAT isozymems in 'Brilliant' indicated that CAT metabolism may play important role in antioxidant defense in the heat-sensitive cultivar of kentucky bluegrass in response to heat stress.

Peroxidases are a variety of enzymes that catalyze the breakdown of $\mathrm{H}_{2} \mathrm{O}_{2}$ with the concomitant dependent oxidation of a wide variety of substrates. In plants, APX uses ascorbate as the specific electron donor in this enzymatic reaction (Teixeira et al., 2006). Its essential role in the scavenging of $\mathrm{H}_{2} \mathrm{O}_{2}$ in chloroplasts, where CAT is absent, has been well established (Asada and Takahashi, 1987). Some studies in annual crops have reported increases in the activities of APX during heat stress (Almeselmani et al., 2006; Chaitanya et al., 2002; Sairam et al., 2000), and this increase is more pronounced in heattolerant cultivars, such winter wheat (Dash and Mohanty, 2002; Sairam et al., 2000). The APX activity in leaves of creeping bentgrass increased with temperatures from optimum $\left(20^{\circ} \mathrm{C}\right)$ to moderate levels $\left(26^{\circ} \mathrm{C}\right)$, but declined to the lowest level at $30{ }^{\circ} \mathrm{C}$ (Xu and Huang, 2004). Results from the current study showed that APX activity increased during heat stress in 'Eagleton' and was significantly higher than that in 'Brilliant' by $28 \mathrm{~d}$. The higher APX activity might enhance the $\mathrm{H}_{2} \mathrm{O}_{2}$ scavenging system in chloroplasts and impair accumulation of $\mathrm{H}_{2} \mathrm{O}_{2}$, resulting in less heat-induced leaf senescence. The reduction of $\mathrm{H}_{2} \mathrm{O}_{2}$ by the ascorbate-glutathione cycle is an extremely efficient reaction that dissipates energy and aids in the adjustment of ATP:NADPH ratios with increasing temperatures (Chaitanya et al., 2002). Plants have multiple APX isozymes. In this study, three APX isozymes were detected in kentucky bluegrass in response to heat stress. APX 2 with Rf 0.58 was enhanced by heat stress in both cultivars, which corresponded to the increase in APX activity. However, the presence of this isozyme in kentucky bluegrass may not be related to the cultivar differences in heat tolerance, as APX isozymes exhibited the same responses in both cultivars differing heat tolerance.

Peroxidases participate in a number of physiological processes, such as plant development and organogenesis (O’Neil and Sccot, 1987; Schneider and Wightman, 1974). The POD activities in leaves and roots of heat-stressed plants increased to levels significantly above their respective controls for two cultivars of bentgrass at $28 \mathrm{~d}$ of heat stress $\left(35 / 25^{\circ} \mathrm{C}\right.$, day/night) (Liu and Huang, 2000). Results from former studies suggest that increases in POD activity are related to an accelerated production of ROS in some plant species (Okuda et al., 1991); however, the elevated activities of POD did not appear to have relieved maize (Zea mays) plants from excessive generation of ROS (Kumar et al., 2008). In the current study, a decline in POD activity was observed during heat stress, and, to a similar extent, in both cultivars during the 28-d heat treatment. Decreases in POD activity during heat stress were also observed in other species, such as wheat (Almeselmani et al., 2006). Heatinduced decline in POD activities in both cultivars suggested that POD could be sensitive to high temperatures, and the enzyme activity was not related to heat tolerance in kentucky bluegrass. Although peroxidases are catalytically very active, they exhibit very little specificity for substrates and exist in various isozyme forms (Gaspar et al., 1991; Siegel, 1993; Welinder, 1992). The expression of specific isozymes has been found responsive to development events such as senescence (Abeles et al., 1988) and external stress, such as wounding and pathogens (Albert and Anderson, 1987). In this study, eight
POD enzymes were detected at normal temperature and heat stress, suggesting that all of these isozymes were constitutively present in kentucky bluegrass. Three isozymes, POD1 (Rf 0.06), POD2 (Rf 0.13), and POD3 (Rf 0.21), showed differential responses to heat stress between the two cultivars, which exhibited a transient increase at $7 \mathrm{~d}$ of heat stress in 'Eagleton' but remained unchanged in 'Brilliant'. Certain POD isomers use the phenolic compounds and $\mathrm{H}_{2} \mathrm{O}_{2}$ to initiate the biosynthesis of several secondary metabolites required for plant growth, development, and differentiation (Gaspar et al., 1991). The transient increase in POD isozyme intensity may reflect transient $\mathrm{H}_{2} \mathrm{O}_{2}$ production during the early phase of heat stress and/or changes in the production of secondary metabolites for stress defense.

In summary, our results demonstrate that antioxidant enzymes and their isozyme forms responded differently to heat stress in two cultivars of kentucky bluegrass. Superior heat tolerance in 'Eagleton', as indicated by lesser heat-induced leaf senescence and other physiological changes (He and Huang, 2007), could be associated with antioxidant protection through increasing activities and maintaining isozymes of SOD for $\mathrm{O}_{2}$ scavenging and increasing APX activities for $\mathrm{H}_{2} \mathrm{O}_{2}$ scavenging. Thus, a tolerant genotype preferably should have greater expression of most of the antioxidant enzymes, such as SOD and Halliwell-Asada Pathway enzymes, such as APX. The lack of cultivar differences in CAT and POD activities or their isozymes could not account for the cultivar variation in heat tolerance in kentucky bluegrass. Manipulation of those antioxidant enzymes that exhibited differential responses to heat stress for cultivars differing in heat tolerance may lead to improvement in heat tolerance. The direction involvement, cellular location, characteristics of these enzymes, and the isoforms related to heat tolerance in perennial grasses are largely unknown, and deserve further investigation.

\section{Literature Cited}

Abeles, F.B., L.J. Dunn, P. Morgens, A. Callman, R.E. Dinterman, and J. Schmidt. 1988. Induction of $33-\mathrm{kD}$ and $60-\mathrm{kD}$ peroxidases during ethylene-induced senescence of cucumber cotyledons. Plant Physiol. 87:609-615.

Aebi, H. 1984. Catalase in vitro. Methods Enzymol. 105:121-126. Albert, F. and A.J. Anderson. 1987. The effect of Pseudomonas putida colonization on root surface peroxidase. Plant Physiol. 85:537-541. Almeselmani, M., P.S. Deshmukh, R.K. Sairam, S.R. Kushwaha, and T.P. Singh. 2006. Protective role of antioxidant enzymes under high temperature stress. Plant Sci. 171:382-388.

Amako, K., G.X. Chen, and K. Asada. 1994. Separate assays specific for ascorbate peroxidase and guaiacol peroxidase and for the chloroplastic and cytosolic isozymes of ascorbate peroxidase in plants. Plant Cell Physiol. 35:497-504.

Arnon, D.I. 1949. Copper enzymes in isolated chloroplasts. Polyphenol oxidase in Beta vulgaris. Plant Physiol. 24:1-15.

Asada, K. 1992. Ascorbate peroxidase: A hydrogen peroxide-scavenging enzyme in plants. Physiol. Plant. 85:235-241.

Asada, K. and M. Takahashi. 1987. Production and scavenging of active oxygen in photosynthesis, p. 227-287. In: D.J. Kyle, C.B. Osmond, and C.J. Arntzen (eds.). Photoinhibition. Elsevier, Amsterdam, The Netherlands.

Asada, K., C. Miyake, S. Sano, and K. Amako. 1993. Scavenging of hydrogen peroxide in photosynthetic organisms from catalase to ascorbate peroxidase, p. 243-250. In: K.G. Welinder, S.K. Rasmussen, H. Penel, and H. Greppin (eds.). Plant peroxidases: Biochemistry and physiology. University of Geneva, Geneva, Switzerland.

Beard, J.B. 1973. Turfgrass: Science and culture. Prentice-Hall, Englewood Cliffs, NJ. 
Beauchamp, C.O. and I. Fridovich. 1973. Isozymes of superoxide dismutase from wheat germ. Biochim. Biophys. Acta 317:50-64.

Bernardi, R., C. Nali, P. Ginestri, C. Pugliesi, G. Lorenzini, and M. Durante. 2001. Antioxidant enzyme isoenzymes on gels in two poplar clones differing in sensitivity after exposure to ozone. Biol. Plant. 48:41-48.

Bonos, S. and J. Murphy. 1999. Growth responses and performance of kentucky bluegrass under summer stress. Crop Sci. 39:770-774.

Bowler, C., M.V. Montagu, and D. Inze. 1992. Superoxide dismutase and stress tolerance. Annu. Rev. Plant Physiol. Plant Mol. Biol. 43:83-116.

Chaitanya, K.V., D. Sundar, S. Masilamani, and A.R. Reddy. 2002. Variation in heat stress-induced antioxidant enzyme activities among three mulberry cultivars. Plant Growth Regulat. 36:175-180.

Chance, B. and A.C. Maehly. 1955. Assay of catalases and peroxidases. Methods Enzymol. 11:764-775.

Dash, S. and N. Mohanty. 2002. Response of seedlings to heat-stress in cultivars of wheat: Growth temperature-dependent differential modulation of photosystem 1 and 2 activity, and foliar antioxidant defense capacity. Plant Physiol. 159:49-59.

Dat, J.F., H. Lopez-Dalgado, C.H. Foyer, and I.M. Scott. 1998. Parallel changes in $\mathrm{H}_{2} \mathrm{O}_{2}$ and catalase during thermotolerance induced by salicylic acid or heat acclimation in mustard seedlings. Plant Physiol. 116:1351-1357.

Elkahoui, S., J.A. Hernández, A. Chedly, G. Rachid, and L. Férid. 2005. Effects of salt on lipid peroxidation and antioxidant enzyme activities of Catharanthus roseus suspension cells. Plant Sci. 168:607-613.

Elstner, E.F. 1982. Oxygen activation and oxygen toxicity. Annu. Rev. Plant Physiol. 33:73-96.

Foster, J.G. and G.E. Edwards. 1980. Localization of superoxide dismutase in leaves of $\mathrm{C}_{3}$ and $\mathrm{C}_{4}$ plants. Plant Cell Physiol. 21:895-906.

Foyer, C.H., H. Lopez-Delgado, J.F. Dat, and I.M. Scott. 1997. Hydrogen peroxide- and glutathione-associated mechanisms of acclimatory stress tolerance and signaling. Physiol. Plant. 100:241-254.

Foyer, C.H., P. Descourvieres, and K.J. Kunert. 1994. Protection against oxygen radicals: An important defense mechanism studied in transgenic plants. Plant Cell Environ. 17:507-523.

Gaspar, T., C. Penel, D. Hagega, and H. Greppin. 1991. Peroxidases in plant growth, differentiation and development process, p. 249-280. In: J. Lobarzewski, H. Greppin, C. Penel, and T. Gaspar (eds.). Biochemical, molecular, and physiological aspects of plant peroxidases. University of Geneva, Geneva, Switzerland.

Giannopolitis, C.N. and S.K. Ries. 1977. Superoxide dismutases I. Occurrence in higher plants. Plant Physiol. 59:309-314.

Gong, M., S.N. Chen, Y.Q. Song, and Z.G. Li. 1997. Effect of calcium and calmodulin on intrinsic heat tolerance in relation to antioxidant systems in maize seedlings. Aust. J. Plant Physiol. 24:371-379.

He, Y. and B. Huang. 2007. Protein changes during heat stress in three kentucky bluegrass cultivars differing in heat tolerance. Crop Sci. 47:2513-2520.

He, Y., Y. Liu, Q. Chen, A. Bian, and W. Chen. 2001. Optimal pH for four antioxidant enzymes in the seedlings of tall fescue and kentucky bluegrass. J. Nanjing Agr. Univ. 24:1-4.

He, Y., Y. Liu, W. Cao, M. Huai, B. Xu, and B. Huang. 2005. Effects of salicylic acid on heat tolerance associated with antioxidant metabolism in kentucky bluegrass. Crop Sci. 45:988-995.

Hiscox, J.D. and G.F. Israelstam. 1979. A method for extraction of chlorophyll from leaf tissue without maceration using dimethyl sulfoxide. Can. J. Bot. 57:1332-1334.

Hoagland, C.R. and D.I. Arnon. 1950. The solution-culture method for growing plants without soil. California Agr. Expt. Sta. Circ. 347.

Jiang, Y. and B. Huang. 2001a. Drought and heat stress injury to two cool-season turfgrasses in relation to antioxidant metabolism and lipid peroxidation. Crop Sci. 41:436-442.

Jiang, Y. and B. Huang. 2001b. Effects of calcium on antioxidant activities and water relations associated with heat tolerance in two cool-season grasses. J. Expt. Bot. 52:341-349.
Kim, S.Y., J.H. Lim, M.R. Park, Y.J. Kim, T. Park, Y.W. Seo, K.G. Choi, and S.J. Yun. 2005. Enhanced antioxidant enzymes are associated with reduced hydrogen peroxide in barley roots under saline stress. J. Biochem. Mol. Biol. 38:218-224.

Kumar, P., R.K. Tewari, and P.N. Sharma. 2008. Cadmium enhances generation of hydrogen peroxide and amplifies activities of catalase, peroxidases and superoxide dismutase in maize. J. Agron. Crop Sci. 194:72-80.

Laemmli, U.K. 1970. Cleavage of structural proteins during the assembly of the head of bacteriophage T4. Nature 227:680-685.

Larkindale, J. and B. Huang. 2004. Changes of lipid composition and saturation level in leaves and roots for heat-stressed and heatacclimated creeping bentgrass (Agrostis stolonifera). Environ. Exp. Bot. 51:57-67.

Lee, S.H. and C.S. An. 2005. Differential expression of three catalase genes in hot pepper (Capsicum annuum L.). Mol. Cell 20:247-255.

Levine, D.M., P.P. Ramsey, and R.K. Smidt. 2001. Applied statistics for engineers and scientists: Using Microsoft Excel and MINITABLE. Prentice-Hall, Upper Saddle River, NJ.

Lin, Z., C. Peng, X. Xu, G. Lin, and J. Zhang. 2005. Thermostability of photosynthesis in two new chlorophyll b-less rice mutants. Science China Ser. C. Life Sci. 48(2):139-147.

Liu, X. and B. Huang. 2000. Heat stress injury in relation to membrane lipid peroxidation in creeping bentgrass. Crop Sci. 40:503-510.

Meriga, B., B.K. Reddy, K.R. Rao, L.A. Reddy, and P.B.K. Kishor. 2004. Aluminium-induced production of oxygen radicals, lipid peroxidation and DNA damage in seedlings of rice (Oryza sativa). J. Plant Physiol. 161:63-68.

Mittler, R. and B.A. Zilinskas. 1993. Detection of ascorbate peroxidase activity in native gels by inhibition of the ascorbate-dependent reduction of nitroblue tetrazolium. Anal. Biochem. 212:540-546.

Mori, H., K. Hogo, H. Higo, Y. Minobe, H. Matsui, and H.S. Chiba. 1992. Nucleotide and derived amino acid sequence of a catalase cDNA isolated from rice immature seeds. Plant Mol. Biol. 18:973-976.

Nakano, Y. and K. Asada. 1981. Hydrogen peroxide is scavenged by ascorbate-specific peroxidase in spinach chloroplasts. Plant Cell Physiol. 22:867-880.

Okuda, T., Y. Matsuda, A. Yamanaka, and S. Sagisaka. 1991. Abrupt increase in the level of hydrogen peroxide in leaves of winter wheat is caused by cold treatment. Plant Physiol. 97:1265-1267.

O'Neil, R.A. and T.K. Sccot. 1987. Rapid effects of IAA on cell surface proteins from intact carrot suspension culture cells. Plant Physiol. 84:443-446.

Ostrovskaya, L.K., V.V. Truch, and O.M. Mikhailik. 2009. Superoxide dismutase activation in response to lime-induced chlorosis. New Phytol. 114:39-45.

Parida, A.K., A.B. Das, and P. Mohanty. 2004. Defense potentials to $\mathrm{NaCl}$ in a mangrove, Bruguiera parviflora: Differential changes of isoforms of some antioxidant enzymes. J. Plant Physiol. 161:531-542.

Ros Barceló, A., R. Muñoz, and F. Sabater. 1987. Lupin peroxidases. I. Isolation and characterization of cell wall-bound isoperoxidase activity. Physiol. Plant. 71:448-454.

Sairam, R.K., G.C. Srivastava, and D.C. Saxena. 2000. Increased antioxidant activity under elevated temperatures, a mechanism of heat stress tolerance in wheat genotypes. Biol. Plant. 43:245-251.

Sato, Y., T. Murakami, H. Funatsuki, S. Matsuba, H. Saruyama, and M. Tanida. 2001. Heat shock-mediated APX gene expression and protection against chilling injury in rice seedlings. J. Expt. Bot. $52: 145-151$

Scandalios, J.G. 1992. Molecular biology of free radical scavenging systems. Cold Spring Harbor Laboratory Press, Cold Spring Harbor, NY.

Scandalios, J.G. 1993. Oxygen stress and superoxide dismutases. Plant Physiol. 101:7-12.

Schneider, E.A. and F. Wightman. 1974. Metabolism of auxin in higher plants. Annu. Rev. Plant Physiol. 25:487-513.

Siegel, B.Z. 1993. Plant peroxidases: An organismic perspective. Plant Growth Regulat. 12:303-312. 
Steel, R.G.D. and J.H. Torrie. 1980. Principles and procedures of statistics. 2nd ed. McGraw-Hill, New York.

Streitweiser, A.J. and C.H. Heathcock. 1976. Introduction to organic chemistry. MacMillan, New York.

Teixeira, F.K., L. Menezes-Benavente, V.C. Galvao, R. Margis, and M. Margis-Pinheiro. 2006. Rice ascorbate peroxidase gene family encodes functionally diverse isoenzymes localized in different subcellular compartments. Planta 224:300-314.

Wang, Z., J. Pote, and B. Huang. 2003. Responses of cytokinins, antioxidant enzymes, and lipid peroxidation in shoots of creeping bentgrass to high root-zone temperatures. J. Amer. Soc. Hort. Sci. 128:648-655.

Welinder, K.G. 1992. Superfamily of plant, fungal and bacterial peroxidases. Curr. Opin. Struct. Biol. 2:388-393.
Woodbury, W., A.K. Spencer, and M.A. Stahmann. 1971. An improved procedure using ferricyanide for detecting catalase isozymes. Anal. Biochem. 44:301.

$\mathrm{Xu}, \mathrm{Q}$. and B. Huang. 2004. Antioxidant metabolism associated with summer leaf senescence and turf quality decline for creeping bentgrass. Crop Sci. 44:553-560.

Zhang, F., Y.L. Yang, W.L. He, F. Sun, and L.X. Zhang. 2004. Changes of antioxidant enzymes in wheat subjected to water deficit and rewatering. Acta Botanica Boreali-Occidentalia Sinica 24:205-209.

Zhang, J. and M.B. Kirkham. 1996. Antioxidant responses to drought in sorghum and sunflower. New Phytol. 132:361-373.

Zhang, X., K. Wang, and E.H. Ervin. 2010. Optimizing dosages of seaweed extract-based cytokinins and zeatin riboside for improving creeping bentgrass heat tolerance. Crop Sci. 50:316-320. 